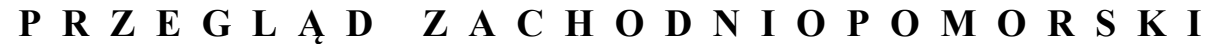 ROCZNIK XXXV (LXIV) ROK 2020 ZESZYT 2
}

\section{$\begin{array}{lllllllll}\mathbf{A} & \mathbf{R} & \mathbf{T} & \mathbf{Y} & \mathbf{K} & \mathbf{U} & \mathbf{L} & \mathbf{Y}\end{array}$}

\author{
AgNiEsZKa BorysowsKA \\ https://orcid.org/0000-0003-3638-4248 \\ Książnica Pomorska w Szczecinie \\ a.borysowska@ksiaznica.szczecin.pl
}

\section{Pomerania litterata. Benjamin Potzerne (1665-1699) I HISTORIA JEGO PROJEKTU}

Słowa kluczowe: Benjamin Potzerne, Pomorze, XVII wiek, bibliografia, leksykon biograficzny

Keywords: Benjamin Potzerne, Pomerania, $17^{\text {th }}$ century, bibliography, biographical lexicon

Kiedy Johann Micraelius (1597-1658), erudyta i pedagog pomorski, przez lata pełniący obowiązki rektora Pedagogium Książęcego w Szczecinie, kończył swoją obszerną syntezę dziejów Pomorza - Altes Pommerland ${ }^{1}$ - nie mógł pewnie przypuszczać, że jeden z krótkich aneksów, który dołączył do ostatniej, szóstej księgi dzieła, stanie się pół wieku później twórczym impulsem dla innego uczonego, także rdzennego Pomorzanina i rektora jedynego pomorskiego uniwersytetu, żyjącego jednak i działającego w zupełnie już innych realiach politycznych. Owym inspirującym dodatkiem było zestawienie książek wydanych przez autorów pomorskich, który w spisie treści nosi łaciński tytuł Catalogus librorum in Pomerania et a Pomeranis ab Anno 1606 editorum, zaś w miejscu publikacji nagłówek Ein Register der Bücher so die Gelehrten in und ausser Pommern von

1 Johann Micraelius, Altes Pommerland: Teutsch. Wendisch Sächsisch; Nebenst Historischer Erzehlung, dero in Nähisten Dreißig Jahren, biß auff des Letzten Hertzogen Bogißlai XIV. Todt, in Pommern Vorgegangenen Geschichten. Buch 1-6 (Alten Stettin: Rhete, 1639-1640). 
1606 heraussgeben ${ }^{2}$. Spis ten jest $\mathrm{w}$ istocie pierwszą bodaj pomorską bibliografią narodową ${ }^{3}$ - jej zakres obejmuje książki wydane przez Pomorzan na Pomorzu lub poza nim, a więc zawiera - jak byśmy to określili per analogiam dla terminu spopularyzowanego przez Karola Estreichera - pomeranica; jej zasięg chronologiczny stanowią natomiast lata 1606-1639, podyktowane założeniami dzieła Micraeliusa.

Naturalnie, tak jak w przypadku innych spisów bibliograficznych sporządzonych w tamtych czasach, zastosowana metoda znacząco odbiega od standardów współczesnego opisu bibliograficznego, co często utrudnia identyfikację prezentowanych dokumentów. Zestawienie sporządził Micraelius w układzie chronologicznym, umieszczając pod każdą datą roczną listę publikacji według wydzielonych graficznie haseł autorskich. Po nazwisku twórcy, podanym przeważnie wraz ze stopniem naukowym i pełnioną funkcją, następuje tytuł dzieła (lub tytuły, jeżeli autor wydał w tym samym roku więcej pozycji), zwykle w bardzo skróconej formie i bez podania adresu wydawniczego. Nazwy publikacji mają niekiedy formę omowną, np. rok 1633 rozpoczyna się wpisem: Funebria regis Suecorum plurima, pod którym kryją się najpewniej okolicznościowe druki różnych autorów, napisane w związku z pochówkiem zmarłego 16 listopada 1632 roku Lwa Północy - Gustawa II Adolfa ${ }^{4}$.

Jak już wcześniej wspomniano, na ten właśnie fragment opracowania Micraeliusa wskazał po latach w swoim projekcie naukowym inny uczony - Benjamin Potzerne 5 . Urodził się on 25 kwietnia 1665 roku w Szczecinie w rodzinie inspektora celnego Daniela Potzernego, miał także starszego brata, Daniela Gottlieba (1660-1700), późniejszego urzędnika podatkowego. Wstępne nauki Benjamin pobierał w swoim rodzinnym mieście, być może był nawet słuchaczem

\footnotetext{
2 Micraelius, Altes, Buch 6, $\mathrm{ii}_{4}-\mathrm{kk}_{4} \mathrm{r}$.

3 Celowo używam określenia „narodowa” (a nie „regionalna”), gdyż świadomość bycia Pomorzaninem, a więc przynależności do Pomorza, jako wspólnoty ludzi żyjących na tym samym terytorium, połączonych językiem, stosunkami gospodarczymi itd., jest w dziele Micraeliusa bardzo widoczna, warto także nadmienić, że w czasie powstawania tego dzieła Pomorze zachowywało jeszcze odrębność państwową.

${ }^{4}$ Micraelius, Altes, Buch 6, $\mathrm{kk}_{3} \mathrm{v}$.

5 Informacje biograficzne zaczerpnięto z: Johann Heinrich Zedler, Grosses vollständiges Universal-Lexicon Aller Wissenschafften und Künste, t. 28 (Leipzig: Johann Heinrich Zedler, 1741), szpalta 1921-1922 (Potzerne oder Pozerne); zob. też Amandus Karl Vanselow, Gelehrtes Pommern Oder Alphabetische Verzeichniss, Einiger in Pommern Gebohrnen Gelehrten, Männlichen und weiblichen Geschlechtes, Nach ihren Merckwürdigsten Amständen Und Verfertigten Schrifften (Stargard: Johann Tiller, 1728), 85-86.
} 
Gymnasium Regium Carolinum, czyli zreformowanego przez władze szwedzkie dawnego Pedagogium Książęcego, którym przed laty kierował Micraelius. Nie możemy tego jednak potwierdzić, gdyż matrykuła tego gimnazjum została zaprowadzona dopiero w 1679 roku, za rektoratu Johanna Ernsta Pfüla (1640-1705), a do szkoły tej mógł Potzerne wstąpić już w 1677 roku, po ukończeniu dwunastego roku życia ${ }^{6}$. W 1685 roku Potzerne uczył się w Lubece, następnie studiował teologię na uniwersytecie w Wittenberdze i tam właśnie, w 1687 roku, uzyskał magisterium z filozofii ${ }^{7}$. Po krótkim pobycie w Lipsku, Helmstedt i Hamburgu wstąpił na uniwersytet w Kilonii. Z tego okresu zachowały się dwie jego dysputy teologiczne z roku $1688^{8}$. Ostatnim przystankiem na jego edukacyjnej drodze był uniwersytet w Rinteln. W 1691 roku Potzerne rozpoczął pracę na Uniwersytecie w Greifswaldzie - otrzymał tam posadę profesora filozofii. Pięć lat później został wybrany rektorem uczelni i mianowany bibliotekarzem9. Być może przyczyniła się do tego publikacja, którą ogłosił w 1693 roku - opis planowanego dzieła zatytułowanego Pomerania litterata ${ }^{10}$.

\footnotetext{
6 Johann Ernst Pfuel, Album studiosorum Illustris Paedagogy Stetinensis... [rękopis], Książnica Pomorska w Szczecinie, sygn. Rkps 250/2.

${ }^{7}$ Benjamin Potzerne, Exercitatio practica conscientiae moderatrix, in quaestione: utrum studiosus theologiae salva conscientia theologiae studium deserere \& iurisprudentiae aut medicinae se consecrare possit, quam praeside D[omi]n[o] Jo[hanno] Frid[erico] Mayero... solemni disputationis ritu proponet... (Wittebergae: Schultzius, 1687).

${ }^{8}$ Benjamin Potzerne, Quaestionem Theologicam utrum pro veritate religionis apud haereticos convertendos sacramento aliquo contendere liceat? consensu summe Rever[endissimo] Facultat[is] Theologicae Praeside D[omi]n[o] Jo[hanno] Frid[erico] Mayero S[anctae] Theol[ogiae] Doct[ore]... in Academia Holsatorum, quae Kiloni[i] est, Christian-Albertina ad... diem Iulii, Anni R. S. MDCLXXXIIX. solenni disputationis ritu proponet \& edisseret... ([Kiel]: Reumannus, 1688); ibidem, Jesu Fortunante lanx satura variarum positionum theologicarum, quam consentiente Summe Reverendo Theologorum Ordine in Alma Kiloniensi praeside Jo[hanno] Frid[erico] Mayero Doctore \& Professore Theologo postridie Kal[endas] August[as] Anno MDCLXXXIIX. proponet... ([Kiel]: Reumann, 1688).

${ }^{9}$ Zob. Die Rektoren der Universität Greifswald, dostęp 30.04.2020, https://www.unigreifswald.de/universitaet/geschichte/chronik-der-universitaet/rektorenchronik/rektorenchronik-1600-1699.

${ }^{10}$ Benjamin Potzerne, Autoschediasma epistolicum ad Germaniae Gloriosae Patres Conscriptos et Cives Maxime Suos hodie Claros, quo scribendae B[ono] c[um] D[eo] Pomeraniae Litteratae institutum atque consilium aperit, exhibet, commendat... (Schneebergae: Weidnerus, 1693).
} 


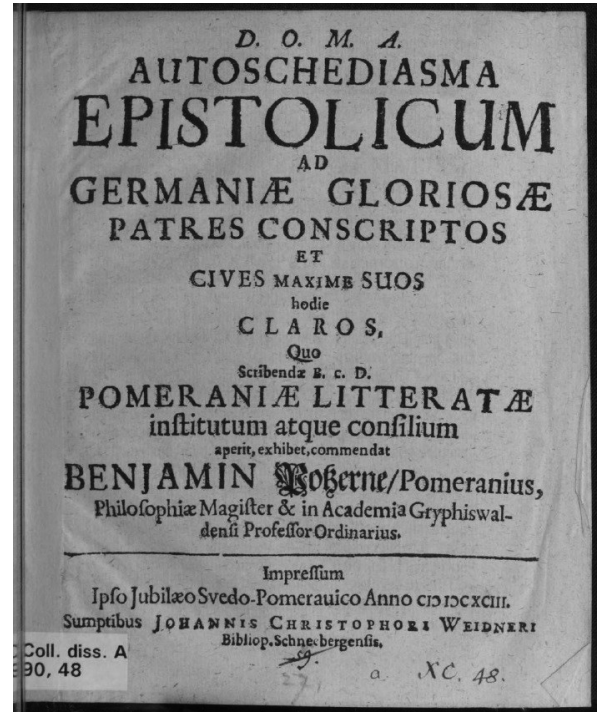

Karta tytułowa broszury informującej o projekcie słownika biobibliograficznego Pomerania litterata Benjamina Potzernego. Źródło: SLUB Dresden: Coll.diss.A.90,48.

Broszura informująca o projekcie Potzernego (ilustracja) zawiera dokładny opis metody, jaką zamierzał zastosować w swoim dziele - słowniku biobibliograficznym, którego, dodajmy, nigdy nie zdołał opracować, gdyż w sześć lat po ogłoszeniu pomysłu, w zaledwie 34. roku życia, zmarł'11. Dzieło, które zamierzał napisać, miało się w swej zasadniczej części składać z haseł osobowych w układzie alfabetycznym. Chciał w nim ująć dane ,wszystkich tych, którzy - albo wywodząc się z Pomorza, częściowo w ojczyźnie, częściowo na innych ziemiach, albo jako urodzeni poza Pomorzem, tu jednak swego czasu żyjąc - rozsławili się wydanymi pismami" " ${ }^{2}$. Część biograficzna hasła miała zawierać nazwisko, imię, daty życia, miejsce pochodzenia, sprawowane urzędy, a także, w pewnych przypadkach, uwzględniać genealogię i tekst epitafium oraz, na ile to możliwe,

${ }^{11}$ Zmarł dokładnie 2 lutego 1699 roku, a 13 marca został pochowany - zob. Die letzte Ehre solten in folgenden Trauer-Zeilen Dem Weyland... Herrn M. Beniamin Potzernen Logices und Metaphysices weitberühmten Prof. Ordinar. auff hiesiger Königl. Universität, nach dem derselbe am 2. Febr. 1699... selig verstorben und am 13. Martii hierauf mit Christlichen Begräbnis-Ceremonien beehret ward mit betrübten Gemühtern ehrerbietigst erweisen Die sämmtlichen hieselbst Studirenden (Greiffswald: Daniel Benjamin Starcken, [1699]).

${ }^{12}$ Potzerne, Autoschediasma, 14-15: ,... omnium eorum, qui sive ex Pomerania oriundi partim in patria partim alibi terrarum, sive extra Pomeraniam nati, hic tamen aliquando degentes, scriptis editis inclaruerunt". 
odsyłać do pełnego opisu życia i śmierci. Część bibliograficzna każdego hasła miała z kolei zawierać wykaz dzieł opisywanego autora, uwzględniający tytuły, miejsca i daty wydania, formę wydawniczą, a nawet - jeśli to możliwe - omówienie treści wraz z przytoczeniem ocen innych osób czy wskazaniem wywołanych kontrowersji. W zamierzeniach miała to być więc bibliografia adnotowana, uzupełniona dodatkowo poprzez liczne indeksy. Pierwszym z nich miał być indeks nazw miejscowych, który dawałby czytelnikowi orientację co do pochodzenia poszczególnych autorów lub miejsc wydania opisywanych publikacji. Drugi, chronologiczny - wzorowany bezpośrednio na zestawieniu Micraeliusa - miał pozwolić na przedstawienie produkcji wydawniczej w układzie rocznym. Trzeci, który Potzerne nazwał „epistemicznym”, miał pomóc zorientować się w dyscyplinach wiedzy, które reprezentowali opisywani twórcy, natomiast kolejny, określony jako ,aksjomatyczny” - w sprawowanych przez nich godnościach i pełnionych urzędach. Ostatni wreszcie - „indeks praktyczny” - miał wskazywać wśród uczonych Pomorzan budujące przykłady pobożności, a wśród ich dzieł „kompendia uczonej pobożności i pobożnej uczoności”. Oprócz indeksów przewidywał Potzerne jeszcze dwa dodatki: pierwszy - dzieł anonimowych, ogłoszonych pod pseudonimem i prac zbiorowych; drugi - władców, dzięki którym powstały i ukazały się drukiem dzieła, które przyczyniły się dla dobra rzeczpospolitej i Kościoła.

Należy przyznać, że zarysowana przez Potzernego koncepcja publikacji zaskakuje i imponuje proponowaną metodą. Naturalnie, dysponujemy tylko opisem przedsięwzięcia i nie możemy mieć pewności, na ile skrupulatnie autor wypełniłby wszystkie swoje założenia w tekście dzieła, niemniej już w fazie projektu było ono bardzo nowoczesne. Wiele elementów, których obecność przewidział Potzerne w swoim projekcie, z punktu widzenia współczesnej metodyki podnosi sprawność informacyjną bibliografii ${ }^{13}$, a więc zdolność formułowania skutecznej odpowiedzi na różnorodne zapytania czytelników. Pierwszym z nich jest adekwatny do rodzaju bibliografii układ tekstu zasadniczego. Potzerne nie chciał przejąć porządku chronologicznego, jaki zastosował w swoim spisie Micraelius. Układ taki jest zalecany zwłaszcza w bibliografiach zagadnieniowych, mających

${ }^{13}$ Za Henrykiem Sawoniakiem pod pojęciem tym rozumiem „metodę opracowania bibliografii, która łatwo, szybko i niezawodnie zapewnia użytkownikowi dotarcie do odpowiednich - z punktu widzenia jego potrzeb informacyjnych - pozycji w danej bibliografii”, dokładne omówienie tego terminu na przykładach - zob. tegoż, ,Sprawność informacyjna bibliografii polskich w XIX wieku (do 1918 r.)", Przegląd Biblioteczny 39 (1971), 155-174. 
na celu ukazanie historycznego rozwoju piśmiennictwa $\mathrm{z}$ danej dziedziny lub w bibliografiach osobowych podmiotowych - by dać pogląd na rozwój i osadzić w ramach czasowych dzieło opisywanego autora. Dla bibliografii zagadnieniowych właściwszy jest także układ systematyczny lub działowy - a więc taki, który daje dostęp do informacji z punktu widzenia treści dokumentu. Potzerne projektował jednak bibliografię ogólną ${ }^{14}$, dla której zaleca się układ alfabetyczny - i taki właśnie planował zastosować.

Drugim wartym zauważenia elementem, który przewidywał w swej bibliografii Potzerne, były adnotacje wyjaśniające treść publikacji, ważne o tyle, że tytuł dokumentu - co możemy stwierdzić i współcześnie - nie zawsze dokładnie precyzuje podjętą przez autora tematykę. Dostęp do informacji o treści opisanych dokumentów dawałyby także zaplanowane indeksy. Jak zauważa współczesny specjalista: ,prawie każda bibliografia poprawnie opracowana powinna - niezależnie od formy układu - być uzupełniona indeksem lub indeksami, wykazującymi materiał z odmiennego punktu widzenia ${ }^{15}$ ". Niezależnie od tego, czy wszystkie zaproponowane przez Potzernego regestry wydają nam się dzisiaj w równym stopniu przydatne, już sam fakt zastosowania kilku ich odmian przekonuje, że pozwoliłyby przejrzeć treść bibliografii z uwzględnieniem różnych wstępnych przesłanek.

Ostatnią wreszcie właściwością zalecaną przez metodyków bibliografii jest obecność takich rozwiązań edytorskich, które ułatwiają czytelnikom korzystanie ze spisu. Zabiegiem tego rodzaju jest np. wprowadzenie numeracji pozycji bibliograficznych, co szczególnie ważne przy jednoczesnym stosowaniu indeksów, zastosowanie żywej paginy, zamieszczenie spisu treści, wreszcie - użycie wyróżnień graficznych, takich jak pogrubienia czy zróżnicowana wielkość i krój czcionki. Do tych elementów trudno się odnieść, nie dysponując gotową publikacją, można jednak zakładać, że i w tym względzie miał Potzerne przemyślenia, skoro wprowadził do opisu projektu pewne konkretne uwagi. Jak już wskazano, zasadniczą treść jego słownika biobibliograficznego miały stanowić hasła autorskie uszeregowane alfabetycznie. Pierwszym elementem każdego hasła miało być nazwisko autora wydrukowane - co wyraźnie zaznacza Potzerne - wielkimi czcionkami, natomiast kolejną składową hasła miało być imię, podane małymi

\footnotetext{
${ }^{14}$ Planował umieścić w niej informację bibliograficzną o wszystkich dziełach piśmienniczych powstałych na przestrzeni dziejów na Pomorzu i/lub stworzonych przez Pomorzan.

${ }^{15}$ Sawoniak, Sprawność, 161, jest to podstawowa zasada przygotowania aparatu pomocniczo-informacyjnego bibliografii.
} 
czcionkami i w nawiasie ${ }^{16}$. Konsekwentne zastosowanie takiego rozwiązania z pewnością stworzyłoby wyróżnienia graficzne, które ułatwiłyby rozróżnienie poszczególnych haseł na stronicach dzieła.

Warto pamiętać, że oprócz sprawności informacyjnej drugą najważniejszą cechą określającą przydatność danego spisu bibliograficznego jest jego wartość informacyjna, a o tej decyduje kompletność i jakość zamieszczonego materiału ${ }^{17}$. Na podstawie lektury opublikowanej zapowiedzi możemy wysnuć przypuszczenie, że Potzerne i z tego zdawał sobie sprawę. Zawarł tu bowiem gorący apel do rodaków o pomoc i wsparcie w ,tkaniu” zamierzonego, jak to górnolotnie określił, „płaszcza nieśmiertelności”. Pomoc ta miała polegać na podpowiedziach gdzie, w jakich zbiorach bibliotecznych lub archiwach, mógłby autor odnaleźć interesujące go publikacje, ewentualnie - na przesłaniu tychże, o ile ktoś miałby taką możliwośćc ${ }^{18}$.

Owo wezwanie do współpracy nie wynikało, naturalnie, tylko z dążeń do zapewnienia planowanemu kompendium najwyższej możliwej wartości informacyjnej, ale także z realnej oceny możliwości stworzenia takiego dzieła w pojedynkę. Trzeba pamiętać, że uczeni w XVII stuleciu wciąż nie mieli dostępu do warsztatu naukowego, jaki stanowią dostępne publicznie zbiory bibliotek i archiwów. Niewątpliwie Potzerne, jako pracownik jedynego pomorskiego uniwersytetu, był w tym względzie w uprzywilejowanym położeniu. Jak jednak większość bibliotek ośrodków edukacyjnych tamtych czasów, tak i ten zbiór - powiększany najczęściej poprzez różne zapisy testamentowe i darowizny - nie dawał przecież nadziei na kompletność materiałów. Taki stan decydował m.in. o tym, że każdy niemal uczony tego stulecia gromadził własną bibliotekę, a o powodzeniu różnych projektów naukowych decydował dostęp do produkcji wydawniczej na dany temat $^{19}$. Warto w tym miejscu przytoczyć casus Andreasa Müllera Greiffenhagiusa (1619-1694), orientalisty, który w czasie, kiedy powstawało dzieło Potzernego,

\footnotetext{
${ }^{16}$ Potzerne, Autoschediasma, 15.

${ }^{17}$ Jak zauważa Henryk Sawoniak (Sprawność, 155): „tym większa jest wartość informacyjna, im bardziej zbliża się autor do kompletności w zebraniu potrzebnych i ważnych materiałów - w ramach przyjętych przez siebie założeń".

${ }^{18}$ Potzerne, Autoschediasma, 14: „Conferte ergo, o Nostri, serica, conferte quaeso fila, peplo immortalitatis innectenda: vitas, fata, scripta Pomeranorum, quotquot in Bibliothecis publicis privatisque, aut tabulariis aliis superesse meministis, quae penes me aut Nostros esse dubitetis, horum plena indicia quaeso date, aut, ut ad me deferantur prorsus, ingenue procurate".

${ }^{19}$ Krzysztof Pomian, Przeszłość jako przedmiot wiedzy, Warszawa: Wydawnictwo Uniwersytetu Warszawskiego, 2010), 133-178.
} 
mieszkał od kilkunastu lat w Szczecinie i, przeczuwając zbliżającą się śmierć, intensywnie zabiegał o włączenie swojej prywatnej biblioteki do jakiejś naukowej kolekcji. Wymienił w tej sprawie korespondencję także z Potzernem, jako przedstawicielem Akademii Greifswaldzkiej, zresztą bez powodzenia ${ }^{20}$. Kilkanaście lat wcześniej natomiast, we wstępie do jednego ze swoich tomów o tematyce sinologicznej, wyraźnie wskazał, że rozpoczęcie pracy naukowej w tej dziedzinie możliwe było tylko dlatego, że dopuszczony został do orientalistycznych zbiorów biblioteki elektorskiej w Berlinie ${ }^{21}$.

Paradoksalnie, w przypadku projektu Potzernego problem dostępności ksiąg krzyżuje się ze świadomością ich nadmiaru, gdyż to właśnie multitudo librorum leży u genezy wszystkich przedsięwzięć bibliograficznych już od czasów Kallimacha z Cyreny ${ }^{22}$. Na temat ogromu produkcji wydawniczej po wynalezieniu druku wypowiadało się wielu uczonych minionych epok, spośród tych głosów przywołajmy jeden tylko, ale pochodzący z połowy XVII wieku - Jana Amosa Komeńskiego:

(...) jeśli już Cycero w swoim czasie użalał się na takie rozmnożenie się ksiąg poetów, że na samo tylko czytanie lirycznych poetów nie starczyłoby mu życia, nawet gdyby je podwoił, to cóż dopiero mówić o naszych czasach, kiedy to i tylu łacińskich poetów przybyło, i to najlepszych (których nie znał jeszcze Cycero), (...) ale i tylu historyków, medyków, prawników, teologów itd.; taka lawina pism, że nawet gdyby komuś dano tysiąc lat na to, nie zdołałby wyczerpać tysięcznej części biblioteki²3.

Przytoczone słowa ujawniają z jednej strony wielką tęsknotę uczonych za przyswojeniem całości dorobku piśmienniczego ludzkości, z drugiej - świadomość nierealności takiego przedsięwzięcia. Także wśród bibliografów, którzy próbowali zapanować nad wielością ksiąg poprzez podjęcie wysiłku ich

\footnotetext{
${ }^{20}$ Zachował się list Potzernego do Müllera z początku 1694 roku - zob. Staatsbibliothek zu Berlin, Nachlass Johann Karl Konrad Oelrichs, Nr. 95.

${ }^{21}$ Zob. np. Andreas Müller Greiffenhagius, Hebdomas Observationum de rebus Sinicis (Coloniae Brandenburgicae: Georgius Schultzius, 1674), [6-7]: „Itaque experiebar, quid valerent humeri, in libris Sinicis, qui Bibliothecam Electoralem huius loci ornant"; więcej na ten temat zob. Agnieszka Borysowska, Michał Gierke, „Andreas Müller Greiffenhagius (1630-1694) - konterfekt uczonego orientalisty", Rocznik Chojeński 10 (2018): 109-113.

${ }^{22}$ Dużo miejsca temu zagadnieniu poświęcił Wiesław Pawlak, De eruditione comparanda in humanioribus. Studia z dziejów erudycji humanistycznej w XVII wieku (Lublin: Wydawnictwo KUL, 2012), 143-235.

${ }^{23}$ Jan Amos Komeński, Pampaedia, tłum. Krystyna Remerowa, wstęp i komentarz Bogdan Suchodolski (Wrocław: Ossolineum, 1973), 244-245.
} 
zinwentaryzowania, widoczna jest owa niemożność opisania całości piśmiennictwa. Warto przywołać przykład Konrada Gessnera, który w połowie XVI wieku wydał obszerną bibliografię zaty tułowaną Bibliotheca universalis sive Catalogus omnium scriptorum locupletissimus in tribus linguis Latina, Graeca et Hebraica (Zurych, 1645-1648). Musiał przecież, mimo chęci stworzenia „biblioteki uniwersalnej”24 (a więc bibliografii ogólnej, takiej jak projektowana przez Potzernego), zastosować jakieś kryterium ograniczające liczbę objętych spisem druków co widać w drugiej części tytułu - było nim kryterium języków publikacji.

W projekcie Potzernego, jak już wzmiankowano, wskaźnikiem kwalifikującym dzieło do opisu miała być jego przynależność do pomeraników, rozumianych jako twórczość Pomorzan (z urodzenia lub miejsca działalności). Nie był to oryginalny pomysł akademika z Greifswaldu - w swojej broszurze wskazał on autora, który był dla niego inspiracją ${ }^{25}$. Mowa o Johannie Mollerze (1661-1725), pedagogu z Flensburga, który w roku 1687 opublikował koncepcję swojej pracy bibliograficznej, zatytułowaną Cimbriae litteratae prodromus ${ }^{26}$. Cimbria littera$t a^{27}$ miała być - i w przyszłości rzeczywiście się stała, choć nastąpiło to dopiero w roku 1744, już po śmierci Mollera - słownikiem biobibliograficznym opisującym twórców z regionu Szlezwiku i Holsztynu, a więc z owej tytułowej Cimbrii. Koncepcja Pomeraniae litteratae była zatem w istocie przeniesieniem pomysłu Mollera na dorobek piśmienniczy innego regionu. Moller na kilkunastu stronach broszury zapowiadającej (Cimbriae litteratae prodromus) omówił ideę swojego projektu, a następnie zamieścił spis nazwisk twórców, których życiorysy już posiada, i tych, których biogramy chciałby jeszcze dołączyć do swojej pracy. Na liście znalazły się zarówno osoby zmarłe, jak i żyjące, a kryterium włączającym danego twórcę w krąg zainteresowań Mollera był fakt przyjścia na świat lub działania w krainach Półwyspu Jutlandzkiego. $Z$ tego powodu sylwetki niektórych autorów z pewnością powtarzałyby się w obydwu słownikach, gdyż na kartach

\footnotetext{
${ }^{24}$ Bibliotheca, catalogus, repertorium, inventarium, index - tak tytułowano dzieła bibliograficzne, nim za sprawą Gabriela Naudégo upowszechnił się termin „bibliographia”; zob. Pomian, Przeszłość, 233-252.

${ }^{25}$ Potzerne, Autoschediasma, 8: „Sustulit iam signum ad bene de gentis suae scriptoribus eorundemque historia sperandum Johannes Mollerus Flensburgenisi in quadripartita Isagoge Cimbria litterate. Huius me quantum exemplum movit, tantum, fateor, fata deterruerunt".

${ }^{26}$ Johann Moller, Cimbriae literatae prodromus sive De suis in historia Patriae literaria conatibus... (Slesvigae: Typis Holvveinianis, 1687).

${ }^{27}$ Johann Moller, Cimbria literata sive Scriptorum ducatus utriusque Slesvicensis et Holsatici, quibus et alii vicini quidam accensentur, historia literaria tripartita (Havniae: Gottmann Fridrich Kisel, 1744).
} 
opracowania Mollera znalazło się np. hasło dla urodzonego w Wolinie, ale działającego przez pewien czas na terenie Szlezwiku, Jana Bugenhagena, a także opis urodzonego w Kilonii, choć przez prawie całe życie zawodowe związanego ze Szczecinem, Heinricha Schaeviusa (Schäwe, Schaeve).

Na marginesie warto się jeszcze zastanowić, kogo Potzerne uznałby za uczonego pomorskiego, a w zasadzie - jak mógł rozumieć termin 'Pomorze'. Kiedy bowiem Micraelius pisał swoją syntezę dziejów Pomorza, do którego dołączył znane Potzernemu zestawienie bibliograficzne, istniało jeszcze (choć właśnie nadciągał jego kres) samodzielne księstwo pomorskie. Na równych prawach uczonego pomorskiego w spisie Micraeliusa był więc reprezentowany zarówno Dawid Haerliz ze Stargardu (po podziale księstwa miasto znalazło się w części brandenburskiej Pomorza), jak i Laurenty Luden z Greifswaldu (to miasto po 1653 roku należało do Pomorza Szwedzkiego). Trzeba przy tym zauważyć, że w broszurze prezentującej projekt Pomeraniae litteratae Potzerne zaznacza fakt przynależności swojego miasta do Szwecji - na karcie tytułowej informuje, że ogłasza publikację „,W sam jubileusz szwedzko-pomorski” ${ }^{28}$. Dzieło Potzernego nie zostało ostatecznie napisane i dysponujemy tylko jego projektem, dlatego w sukurs może przyjść inna publikacja z tego czasu. Jest nią dysputa akademicka De Pomerania przedstawiona w roku 1684 na Uniwersytecie we Frankfurcie nad Odrą przez Georga Friedricha Sasse, studenta ze Szczecina, którego opiekunem naukowym był Christian Grüneberg (1639-1701), profesor matematyki, także rodem ze Szczecina ${ }^{29}$. W obszernym wywodzie Pomorze opisane jest tam jako kraina historyczna o określonym, podanym za pomocą współrzędnych geograficznych, położeniu, której część, w konsekwencji aktualnego podziału terytorialnego, przynależy do Królestwa Szwecji, a część - do Elektoratu Brandenburskiego. Nadal jednak dla całości tych ziem, adekwatna jest nazwa Pomorze. $\mathrm{W}$ toku wywodu zamieszczono także tabelę zawierającą nazwy miast pomorskich wraz z ich współrzędnymi geograficznymi, z czego jasno wynika, że do Pomorza nadal wliczane były wszystkie miasta dawnego księstwa pomorskiego - od Barth na zachodzie po Bytów na wschodzie. Tak więc to twórców dzieł piśmienniczych z tych ośrodków należałoby się spodziewać w dziele Potzernego, gdyby ostatecznie powstało.

\footnotetext{
${ }^{28}$ Potzerne, Autoschediasma, k. tyt.: ,impressum ipso jubilaeo Svedo-Pomeranico”.

${ }^{29}$ Georg Friedrich Sasse, Disputatio de Pomerania quam... praeside Dn. Christiano Grünebergen ... exponit... (Francofurti ad Oderam: Christophori Zeitleri, [1684]).
} 
Prawdopodobnie znalazłaby się w niej także sylwetka Daniela Georga Morhofa (1639-1691), z pochodzenia wprawdzie Meklemburczyka, a w dorosłym życiu akademika związanego z Uniwersytetem Kilońskim, ale wcześniej - jednego ze słynniejszych wychowanków szczecińskiego Pedagogium Książęcego. Była to postać ważna dla Potzernego (a wcześniej także dla Mollera) - kilkakrotnie przywołał nazwisko Morhofa w zapowiedzi swojej bibliografii, ukazując go jako inspiratora, który wskazał mu ideę i przekonał o konieczności podjęcia wysiłku stworzenia Pomeraniae litteratae.

Ową ideą była chęć ukazania dokonań piśmienniczych Pomorzan, które wpisałyby się w szerszy krąg dokonań uczonych niemieckich - niesprawiedliwie dotąd ocenianych przez wielu pisarzy wywodzących się z innych narodów. W swoim krótkim opisie Pomeraniae litteratae poświęca Potzerne całą stronę na przytoczenie cytatu ze słynnego Polyhistora Morhofa, na ten właśnie temat ${ }^{30}$. Przywołuje także przykłady owych „Włochów, Greków i Hiszpanów”, których usposobienie każe „inne narody oceniać jako mniej wartościowe od własnych” i którym trudno przyjąć prawdę na temat dokonań piśmienniczych erudytów germańskich, więc próbują rozmaitych wybiegów, takich jak np. sztuczne wywodzenie genealogii rdzennie niemieckich autorów od Rzymian albo Trojan ${ }^{31}$. Po licznych przykładach tego rodzaju niesprawiedliwości odsłania Potzerne główną swoją motywację: „krzywda wspólnej ojczyzny tak mianowicie przepełniła wrażliwe serce, bym, jeśli tylko mogę, powiększył chwałę Germanii”32.

Tego rodzaju pobudki nie były w tamtym czasie niczym nowym. Przywołajmy w tym miejscu rodzimy przykład: Szymona Starowolskiego (1588-1656), który we wstępie do swojego słownika biobibliograficznego uczonych polskich Scriptorum Polonicorum hekatontas, seu centum illustrium Poloniae scriptorum elogia et vitae - tak przedstawiał powody chwycenia za pióro:

Jest to zaiste dziełko drobne i niepozorne, jeśli się patrzy na rozmiary książki i powagę stylu; nie należy go jednak lekceważyć ze względu na zawartość i powód, dla

\footnotetext{
${ }^{30}$ Potzerne, Autoschediasma, 7 - przytacza tu autor obszerny passus z dzieła Daniela Georga Morhofa (Polyhistor sive De notitia auctorum et rerum commentarii, Lubecae: sumptibus Petri Böckmanni, 1688, 208).

${ }^{31}$ Potzerne, Autoschediasma, 4: „Commune id esse Italorum, Graecorum et Hispanorum ingeniis, nationes quascunque viliores suis pendere, historiae annotarunt", konkretne przykłady takich autorów na s. 4-7.

${ }^{32}$ Potzerne, Autoschediasma, 8: „Communis siquidem patriae contemtus imbuebat facile pectus commiseratione, ut si qua possem, Gloriam Germaniae promoverem”.
} 
którego zostało napisane. Bowiem wśród narodów o wysokiej kulturze wielu jest ludzi, którzy - z wielkim naszym podziwem - nie tylko nazywają nas, mieszkańców Północy, barbarzyńcami, lecz także uważają nas za zupełnie obcych wszelkiej kulturze. (...) Na pewno nie ma takiego kraju, pod szczęśliwą czy złowrogą gwiazdą, którego synowie nie posiadaliby mnóstwa wad i jednocześnie wielu zalet. A więc i my także, choć mieszkamy w pobliżu mroźnego bieguna, nie jesteśmy tak dalece pogrążeni w mrokach niewiedzy, jak to opacznie sądzą o nas niektórzy, nawet bliscy sąsiedzi: lecz oświeceni tym samym słońcem, co inni, mamy pośród siebie niezliczone przykłady znakomitych cnót, a także czcigodne pomniki pozostawione przez ludzi wielkiego umysłu ${ }^{33}$.

Wspomniani w ostatnim zdaniu ,ludzie wielkiego umysłu” to, oczywiście, opisany w książce Starowolskiego poczet autorów polskich, którzy w czasie już minionym pozostawili po sobie „czcigodne pomniki” w postaci dzieł piśmienniczych. Takie samo podejście widoczne jest i u Potzernego. Ujawnia się ono nie tylko w opisie, ale i w tytule jego projektu - za sformułowaniem ,uczone Pomorze" (Pomerania litterata) kryje się przecież grono erudytów pomorskich, którzy pozostawili po sobie różnorodne pisma. Tytuł ten przywodzi ponadto na myśl inny używany w epoce termin: respublica litteraria (rzeczpospolita pisarska, rzeczpospolita uczonych), a w połączeniu z ujawnioną motywacją Potzernego, którą miało być przysporzenie chwały Germanii, łatwo odnaleźć w nim humanistyczną ideę uobecnienia tekstowego i literackiej nieśmiertelności ${ }^{34}$. Przywołajmy raz jeszcze świadka epoki, Jana Amosa Komeńskiego, który owe znane przynajmniej od czasów Horacego koncepcje wyraził expressis verbis: „Wspaniałymi rzeczami są zbudowane z pisma książki, w których odtworzoną mądrość przesyłamy ludziom nieobecnym w danym miejscu i czasie, nawet w najpóźniejsze przyszłe pokolenia" 35 .

${ }^{33}$ Szymon Starowolski, Setnik pisarzów polskich albo pochwaty i żywoty stu najznakomitszych pisarzów polskich, tłum. i komentarz Jerzy Starnawski, wstęp Franciszek Bielak i Jerzy Starnawski (Kraków: Wydawnictwo Literackie, 1970), 39.

${ }^{34}$ Opisuje to obszernie w swojej książce (zwłaszcza w rozdz. XIV: Respublica litteraria między uobecnieniem tekstowym a majaczeniem sennym) Juliusz Domański, Tekst jako uobecnienie. Szkic z dziejów myśli o piśmie i książce (Kęty: Antyk, 2002), zob. też Europäische Bildungströme. Die Viadrina im Kontext der europäischen Gelehrtenrepublik der Frühen Neuzeit (1506-1811) (Schöneiche bei Berlin, 2008).

${ }^{35}$ Jan Amos Komeński, „Żywa typografia, to jest sztuka oszczędnego a przecież masowego $i$ wybornego odbijania madrości nie na papierze, lecz w umyśle", w: tegoż, Pisma wybrane, tłum. Krystyna Remerowa, wybór, wstęp i komentarz Bogdan Suchodolski (Wrocław-Warszawa-Kraków: Ossolineum, 1964), 539. 
Naturalnie, owo unieśmiertelnienie w ujęciu diachronicznym objęłoby także i Potzernego jako twórcę dzieła, a przy tym pozwoliłoby mu przekroczyć granicę rzeczpospolitej pisarskiej zupełnie współcześnie. Łaciński termin respublica litteraria, nie zatracając całkiem swych wcześniejszych znaczeń, ewoluował bowiem tak, że w czasach Potzernego denotował już także „społeczność teraźniejszą, realną, fizycznie stwierdzalną, choć konstytuowaną przez treści i wartości duchowe, aktualną społeczność uczonych, ludzi piszących i czytających"36. Owa wspólnota, która jako widome świadectwo swego istnienia pozostawiła po sobie przechowywane do dziś w archiwach setki tysięcy listów, wymienianych pomiędzy uczonymi, nie była jednak skłonna przyjąć każdego. Kartą wstępu nie musiał być, bynajmniej, sprawowany urząd, czy, jak w przypadku Potzernego, godności akademickie, ale mogło nią być dzieło piśmiennicze wykazujące tak wielką użyteczność dla uczonych, jaką przedstawiała bibliografia.

Ponadwyznaniowa i międzynarodowa wspólnota uczonych, która na początku XVII wieku do udzielania sobie wiadomości o podjętych projektach, własnych publikacjach i osiągnięciach badawczych wykorzystywała przede wszystkim korespondencję, wobec narastającego wciąż w ciągu tegoż stulecia zjawiska copiae librorum, a także w związku z powiększaniem się własnego środowiska (nie sposób wszak korespondować ze wszystkimi), musiała z czasem stworzyć dodatkowe narzędzia informacji o produkcji wydawniczej. Jak zauważa Krzysztof Pomian, nim rolę medium powiadamiającego o nowościach wydawniczych przyjęły na siebie periodyki, „,w przekazywaniu informacji naukowych, w szczególności - danych o książkach i rękopisach, istotnym uzupełnieniem listów były bibliografie oraz drukowane sprawozdania z podróży badawczych, przewodniki i informatory" ${ }^{37}$. Przemiany te doprowadziły do tego, że ostatecznie na progu XVIII stulecia korespondencja pomiędzy uczonymi przechodzić zaczęła do sfery prywatnej, a jej rolę informacyjną przejmowały coraz liczniejsze i łatwiej dostępne specjalistyczne publikacje. Zaprojektowane w 1693 roku przedsięwzięcie bibliograficzne Potzernego wpisywało się więc w szersze tendencje widoczne w epoce.

Te tendencje uwidaczniają się również w poświęceniu przez Potzernego sporego miejsca w opisie projektu na dywagacje dotyczące otium litteratum (zajęcia naukowe) i publicznego zobowiązania do stworzenia dzieła służącego

\footnotetext{
${ }^{36}$ Domański, Tekst, 173.

${ }^{37}$ Pomian, Przeszłość, 233.
} 
społeczności ${ }^{38}$. Owo poświęcanie działalności naukowej każdej wolnej chwili, oddanie się całkowicie przedsięwzięciu, nieobliczone przy tym na doraźne korzyści, było, jak objaśnia współczesny badacz, jedną z charakterystycznych postaw uczonych przynależnych do rzeczpospolitej pisarskiej. „To pełne identyfikowanie się z wykonywanym zadaniem czerpało swe uzasadnienie - czytamy dalej - z głębokiego przekonania o użyteczności tego, co się czyni. Uprawianie nauki dlatego uważano za sensowne, że dostarcza ono korzyści społeczeństwu

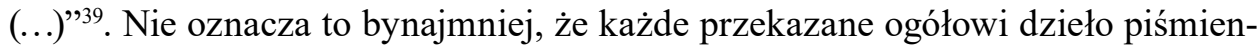
nicze zasługiwało na uznanie, wręcz przeciwnie - uczeni tamtych czasów pozostawili wiele uwag na temat bezużyteczności i zbędności niektórych publikacji ${ }^{40}$. Podejmując się opisania panteonu uczonych pomorskich miał jednak Potzerne przekonanie o potrzebie stworzenia takiego kompendium zagwarantowane przez autorytet Morhofa. W tym samym rozdziale bowiem, na który powołał się Potzerne w swojej broszurze, bezpośrednio po opisie wspomnianego wyżej dzieła Szymona Starowolskiego, zawarł Morhof przepełnioną żalem refleksję: „Obyż i w narodzie niemieckim pojawił się ktoś, kto podejmie tego rodzaju powinność zatroszczenia się o swoją ojczyznę i zsumuje starannie dzieje pisarzy i twórców swojego narodu (...)"41.

Miał Potzerne świadomość, że opisując tylko erudytów z Pomorza, nie wypełni tego zobowiązania w całości i skromnie przewidywał dla swego dzieła pozycję ,gwiazdy nie pierwszej wielkości ${ }^{42}$ ", która jednak znajdzie uznanie w świecie uczonych. Przedwczesna śmierć nie pozwoliła mu się o tym przekonać, podobnie jak o słuszności przewidywań co do czasochłonności przedsięwziętego zadania. Zaświadczają o tym jednak żywoty wielu bibliografów z przeszłości, jak choćby wspomnianego już Johanna Mollera, który ostatecznie nie doczekał edycji swojego kompendium, czy autora, który trzydzieści lat po śmierci Potzernego wydał drukiem pierwszy słownik biobibliograficzny ${ }^{43}$ uczonych pomorskich Amandego Karla Vanselowa (1699-1771). Ten prowincjonalny burmistrz z Płot

\footnotetext{
${ }^{38}$ Potzerne, Autoschediasma, 9-13.

${ }^{39}$ Pomian, Przeszłość, 273-274.

${ }^{40}$ Obszernie na ten temat Pawlak, De eruditione, 173-209.

${ }^{41}$ Morhof, Polyhistor, 208: „Utinam in Germana gente esset, qui hoc patriae suae pietatis officium praestaret, colligeretque accuratam scriptorum et autorum suae gentis historiam (...)".

${ }^{42}$ Potzerne, Autoschediasma, 14: „Nec coelum reliquas stellas, quae primae magnitudinis non sunt, dedignatur, nec (pie confido) Orbis eruditus Pomeraniam litteratam inficiabitur".

${ }^{43}$ Vanselow, Gelehrtes - zob. przypis 4.
} 
pracował nad swoim dziełem w zasadzie przez całe życie, gdyż po ogłoszeniu w 1728 roku pierwszej jego edycji gromadził materiał nadal i w chwili śmierci pozostawił w rękopisie trzy obszerne tomy drugiej, znacznie poszerzonej wersji na jej karcie tytułowej dopisał jako wariant tytułu dwa słowa: Pomerania litteraria. Niestety, nie miał tyle szczęścia, co Moller, nikt po jego śmierci nie wydał dzieła jego życia. Pozostało ono w rękopisie i przedziwnym zrządzeniem losu trafiło do miasta, w którym koncepcję tego rodzaju kompendium jako pierwszy obmyślił Daniel Potzerne - do Greifswaldu ${ }^{44}$.

\section{Bibliografia}

\section{Źródła niepublikowane}

Książnica Pomorska w Szczecinie, sygn. Rkps 250/2: Pfuel Johann Ernst, Album studiosorum Illustris Paedagogy Stetinensis... [rękopis].

Landesarchiv Greifswald, Rep. 41 Plathe, Nr. I A 1:24: Pommersches Gelehrten-Lexikon. T. 1-3. Dostęp: 8.05.2020. on-line: urn:nbn:de:gbv:9-g-5146617.

Die Rektoren der Universität Greifswald. Dostęp 30.04.2020. https://www.uni-greifswald. de/universitaet/geschichte/chronik-der-universitaet/rektorenchronik/rektorenchronik-1600-1699.

Staatsbibliothek zu Berlin.Nachlass Johann Karl Konrad Oelrichs. Nr. 95: List B. Potzernego do A. Müllera Greffenhagiusa, 1694 r.

\section{Opracowania}

Beckmann, Sabine. „Litterarische Kommunikation zwischen pommerschen Fürstinnen und Gelehrten des 16. und 17. Jahrhunderts". W: Dirk Schleinert, Monika Schneikart, Zwischen Thronsaal und Frawenzimmer. 65-87. Köln: Böhlau Verlag.

Borysowska, Agnieszka, Michał Gierke. „Andreas Müller Greiffenhagius (1630-1694) konterfekt uczonego orientalisty”. Rocznik Chojeński 10 (2018), 93-132.

Die letzte Ehre solten in folgenden Trauer-Zeilen Dem Weyland... Herrn M. Beniamin Potzernen Logices und Metaphysices weitberühmten Prof. Ordinar. auff hiesiger Königl. Universität, nach dem derselbe am 2. Febr. 1699... selig verstorben und am 13. Martii hierauf mit Christlichen Begräbnis-Ceremonien beehret ward mit betrübten Gemühtern ehrerbietigst erweisen Die sämmtlichen hieselbst Studirenden. Greiffswald: Daniel Benjamin Starcken [1699].

${ }^{44}$ Zob. Landesarchiv Greifswald, Rep. 41 Plathe, Nr. I A 1: 24: Pommersches Gelehrten-Lexikon, t. 1-3, dostęp 8.05.2020, on-line: urn:nbn:de:gbv:9-g-5146617; zob. też Sabine Beckmann, „Litterarische Kommunikation zwischen pommerschen Fürstinnen und Gelehrten des 16. und 17. Jahrhunderts", w: D. Schleinert, M. Schneikart, Zwischen Thronsaal und Frawenzimmer (Köln: Böhlau Verlag), 65-87. 
Domański, Juliusz. Tekst jako uobecnienie. Szkic z dziejów myśli o piśmie i książce. Kęty: Antyk, 2002.

Europäische Bildungströme: die Viadrina im Kontext der europäischen Gelehrtenrepublik der Frühen Neuzeit (1506-1811). Schöneiche bei Berlin: Scripvaz, 2008.

Müller Andreas Greiffenhagius. Hebdomas Observationum de rebus Sinicis. Coloniae Brandenburgicae: Georgius Schultzius, 1674.

Komeński, Jan Amos. Pampaedia. Tłum. Krystyna Remerowa. Wstęp i komentarz Bogdan Suchodolski. Wrocław: Ossolineum, 1973.

Komeński, Jan Amos. „Żywa typografia, to jest sztuka oszczędnego a przecież masowego i wybornego odbijania mądrości nie na papierze, lecz w umyśle”. W: tegoż, Pisma wybrane. Tłum. Krystyna Remerowa. Wstęp i komentarz Bogdan Suchodolski. Wrocław-Warszawa-Kraków: Ossolineum, 1964.

Micraelius, Johann. Altes Pommerland: Teutsch. Wendisch Sächsisch; Nebenst Historischer Erzehlung, dero in Nähisten Dreißig Jahren, biß auff des Letzten Hertzogen Bogißlai XIV. Todt, in Pommern Vorgegangenen Geschichten. Buch 1-6. Alten Stettin: Rhete, 1639-1640.

Moller, Johann. Cimbria literata sive Scriptorum ducatus utriusque Slesvicensis et Holsatici, quibus et alii vicini quidam accensentur, historia literaria tripartite. Havniae: Gottmann Fridrich Kisel, 1744.

Moller, Johann. Cimbriae literatae prodromus sive De suis in historia Patriae literaria conatibus... Slesvigae: Typis Holvveinianis, 1687.

Morhof, Daniel Georg. Polyhistor sive De notitia auctorum et rerum commentarii. Lubecae: sumptibus Petri Böckmanni, 1688.

Pawlak, Wiesław. De eruditione comparanda in humanioribus. Studia z dziejów erudycji humanistycznej w XVII wieku. Lublin: Wydawnictwo KUL, 2012.

Pomian, Krzysztof. Przeszłość jako przedmiot wiedzy. Warszawa: Wydawnictwo Uniwersytetu Warszawskiego, 2010.

Potzerne, Benjamin. Autoschediasma epistolicum ad Germaniae Gloriosae Patres Conscriptos et Cives Maxime Suos hodie Claros, quo scribendae B[ono] c[um] D[eo] Pomeraniae Litteratae institutum atque consilium aperit, exhibet, commendat... Schneebergae: Weidnerus, 1693.

Potzerne, Benjamin. Exercitatio practica conscientiae moderatrix, in quaestione: utrum studiosus theologiae salva conscientia theologiae studium deserere \& iurisprudentiae aut medicinae se consecrare possit, quam praeside D[omi]n[o] Jo[hanno] Frid[erico] Mayero... solemni disputationis ritu proponet... Wittebergae: Schultzius, 1687. 
Potzerne, Benjamin. Jesu Fortunante lanx satura variarum positionum theologicarum, quam consentiente Summe Reverendo Theologorum Ordine in Alma Kiloniensi praeside Jo[hanno] Frid[erico] Mayero Doctore \& Professore Theologo postridie Kal[endas] August[as] Anno MDCLXXXIIX. proponet... [Kiel]: Reumann, 1688.

Potzerne, Benjamin. Quaestionem Theologicam utrum pro veritate religionis apud haereticos convertendos sacramento aliquo contendere liceat? consensu summe Rever[endissimo] Facultat[is] Theologicae Praeside D[omi]n[o] Jo[hanno] Frid[erico] Mayero S[anctae] Theol[ogiae] Doct[ore]... in Academia Holsatorum, quae Kiloni[i] est, Christian-Albertina ad... diem Iulii, Anni R. S. MDCLXXXIIX. solenni disputationis ritu proponet \& edisseret... [Kiel]: Reumannus, 1688.

Sasse, Georg Friedrich. Disputatio de Pomerania quam... praeside Dn. Christiano Grünebergen... exponit... Francofurti ad Oderam: Christophori Zeitleri [1684].

Sawoniak, Henryk. „Sprawność informacyjna bibliografii polskich w XIX wieku (do 1918 r.)". Przegląd Biblioteczny 39 (1971): 155-174.

Starowolski, Szymon. Setnik pisarzów polskich albo pochwały i żywoty stu najznakomitszych pisarzów polskich. Tłum. i komentarz Jerzy Starnawski. Wstęp Franciszek Bielak i Jerzy Starnawski. Kraków: Wydawnictwo Literackie, 1970.

Vanselow, Amandus Karl. Gelehrtes Pommern Oder Alphabetische Verzeichniss, Einiger in Pommern Gebohrnen Gelehrten, Männlichen und weiblichen Geschlechtes, Nach ihren Merckwürdigsten Amständen Und Verfertigten Schrifften. Stargard: Johann Tiller, 1728.

Zedler, Johann Heinrich. Grosses vollständiges Universal-Lexicon Aller Wissenschafften und Künste. T. 28. Leipzig: Johann Heinrich Zedler, 1741, szpalta 1921-1922 (Potzerne oder Pozerne).

\begin{abstract}
Abstrakt
Pod koniec XVII wieku profesor (później także rektor) Akademii w Greifswaldzie, Benjamin Potzerne (1665-1699), ogłosił projekt słownika biobibliograficznego, w którym miały się znaleźć życiorysy i bibliografia podmiotowa rdzennych Pomorzan, a także innych mieszkańców Pomorza, którzy wydali tu drukiem swoje pisma. Słownik, inspirowany dziełem Johanna Mollera (1661-1725) i Daniela Georga Morhofa (1639-1691), a także, pośrednio, Szymona Starowolskiego (1588-1656), nie został ostatecznie opracowany ze względu na nagłą śmierć autora. W artykule omówiono założenia projektu i ukazano jego miejsce na tle innych dokonań tego typu w epoce.
\end{abstract}




\title{
Pomerania litterata. Benjamin Potzerne (1665-1699) AND THE HISTORY OF HIS PROJECT
}

\begin{abstract}
In the late $17^{\text {th }}$ century professor (later also the rector) of the Academy in Greifswald, Benjamin Potzerne (1665-1699), announced a project of a biobibliographical dictionary which was to contain biographies and the subjective bibliographies of the native Pomeranians, as well as of other inhabitants of Pomerania, who published here their works. The dictionary, inspired by the work of Johann Moller (1661-1725) and Daniel Georg Morhof (1639-1691), and - indirectly - Szymon Starowolski (1588-1656), was not eventually written because of the author's sudden death. The article discusses the assumptions of the project and demonstrates its place among other achievements of this type at the time.
\end{abstract}

